\title{
Probiotic properties of Lactobacillus strains from traditional fermented yogurt in Xinjiang
}

\author{
Ruokun $\mathrm{Yi}^{1, *}$, Fang $\mathrm{Tan}^{2}$, and Xin $\mathrm{Zhao}^{1}$ \\ ${ }^{1}$ Chongqing Collaborative Innovation Center for Functional Food, Chongqing University of Education, Chongqing 400067, China \\ ${ }^{2}$ Department of Public Health, Our Lady of Fatima University, Valenzuela 838, Philippines
}

\begin{abstract}
In this study, 3 Lactobacillus strains isolated from 5 kinds of traditional fermented yogurt in Xinjiang were identified as Lactobacillus plantarum (LP1, LP2), and Lactobacillus delbrueckii subsp. Bulgaricus (LD). Probiotic properties of Lactobacillus strains have been evaluated by testing the tolerance to artificial gastric juice and bile salt, cell surface hydrophobicity, hydroxyl radicals and DPPH free radicals scavenging rates. As the results, LP1 showed better tolerance to acid, cell surface hydrophobicity and antioxidant ability, LP2 showed better tolerance to bile salt comparing with the other two LAB strains. LP1 showed the best probiotic properties in general. These results provide reference value for the probiotic research in vivo and the development of new functional probiotic products in the future.
\end{abstract}

\section{Introduction}

Probiotics are defined as viable microorganisms. When a certain amount of probiotics is ingested, it will produce definite health effects on the host, thus improving the microecological balance of the host and playing a probiotic role [1]. The beneficial effects of probiotics on human health are well known. As a food starter, probiotics are also widely used in food fermentation industry. When probiotics passing through the digestive tract, most of them will be inactivated or the survival rate will be reduced due to the gastric acid and bile salt of intestine. Only living probiotics can show health benefits $[2,3]$. Therefore, screening probiotics that can tolerate human gastrointestinal environment is the focus of recent research of probiotics. As we known, continuous high concentration of reactive oxygen species (ROS) can irreversibly destroy or alter the function of target molecules, resulting in DNA damage, lipid peroxidation and protein oxidation. At the same time, it has been reported that lactic acid bacteria (LAB), as probiotics of intestinal tract, can directly play an antioxidant role in the intestinal tract by maintaining the balance of intestinal oxidation and reduction [4]. In order for probiotics to have beneficial effects on the host, they must survive through the host's digestive tract, adhere to the intestinal mucosa, and have corresponding functions like antioxidant ability [5]. However, there are significant differences in the characteristics of different strains of LAB and even between different strains [6]. Therefore, screening strains with high antioxidant activity and strong tolerance is important for expanding probiotic bank with independent intellectual property rights in China and enhancing the function of fermented food.
Herdsmen in Xinjiang have a long history and rich experience in making traditional yogurt, among which LAB resources are very rich in biodiversity [7]. The isolation of LAB from traditional fermented milk in Xinjiang is of great significance for the enrichment and protection of $\mathrm{LAB}$ resources in China.

The purpose of this research is to study the LAB strains isolated from Xinjiang traditional fermented yogurt, and to test their tolerance to bile salts and gastric acid, as well as cell surface hydrophobicity and antioxidant activity, so as to provide a theoretical basis for further research.

\section{Materials and methods}

\subsection{Bacterial isolation and identification}

5 yogurt samples were collected from Kashi areas in Xinjiang, China. Yogurts were fermented by herdsmen with fresh milk. As shown in Fig.1, traditional fermented yogurt samples presented yellowish cream color and curd state. $10 \%$ diluted samples were plated on MRS agar (Becton, Dickinson and Company, USA) plates containing $3 \% \mathrm{CaCO}_{3}$ (wt/vol). Then incubated at $37^{\circ} \mathrm{C}$ for $48 \mathrm{~h}$. The purified single colony was stained by Gram staining and microscopic observation to identify potential LAB strains [8]. 16S rDNA of the selected strains were amplified by PCR using primers (27F 5'AGAGTTTGATCCTGGCTCAG-3', 1495R 5'CTACGGCTACCTTGTTACGA-3'). DNA sequencing was performed by the Chengdu Zhike Biotechnology Co., Ltd. (Chengdu, China). The 16S gene sequences was examined by comparing the obtained sequences by the

\footnotetext{
Corresponding author: zhaoxin@cque.edu.cn
} 
BLAST program in the National Center for Biotechnology Information (NCBI) database.

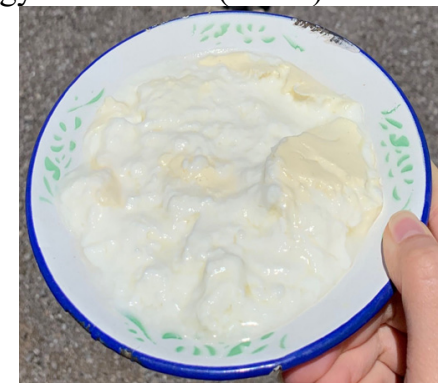

Fig. 1. Traditional fermented yogurt sample from Xinjiang, China.

\subsection{Tolerance to acid and bile salt}

The preparation of artificial gastric juice refers to the appendix 10 of Chinese Pharmacopoeia [9]. LAB strains were incubated in MRS medium at $37^{\circ} \mathrm{C}$ for $24 \mathrm{~h}$, centrifuged $\left(10000 \mathrm{rpm}, 10 \mathrm{~min}, 4^{\circ} \mathrm{C}\right)$ and washed twice with PBS buffer $(\mathrm{pH}=7.2)$. Inoculated in artificial gastric juice at $2 \%(\mathrm{v} / \mathrm{v})$ inoculation volume, and then incubated at $37^{\circ} \mathrm{C}$, the total viable counts were measured at $0 \mathrm{~h}$ and $3 \mathrm{~h}$ respectively.

Survival rates $(\%)=[3 \mathrm{~h}$ viable counts $(\mathrm{CFU} / \mathrm{mL}) / 0 \mathrm{~h}$ viable counts $(\mathrm{CFU} / \mathrm{mL})] \times 100 \%$.

To screen for tolerance to bile salt, the LAB cultures were incubated at $37^{\circ} \mathrm{C}$ overnight, then culture liquid was inoculated into MRS-THIO medium containing different concentrations of bovine bile salt (Sinopharm Chemical Reagent Company, Shanghai, China) respectively according to $2 \%$ inoculation amount. Samples were incubated at $37^{\circ} \mathrm{C}$ for $24 \mathrm{~h}$, MRS-THIO medium served as blank controls, OD $_{600 \mathrm{~nm}}$ was determined [10].

Survival rates $(\%)=\left[\mathrm{OD}_{600 \mathrm{~nm}}(\mathrm{MRS}-\mathrm{THIO}\right.$ medium containing bile salt) $/ \mathrm{OD}_{600 \mathrm{~nm}}$ (blank MRS-THIO medium) $] \times 100 \%$.

\subsection{Cell surface hydrophobicity}

$5 \mathrm{~mL}$ overnight culture liquid were collected and centrifuged $\left(4000 \mathrm{rpm}, 10 \mathrm{~min}, 4^{\circ} \mathrm{C}\right)$. Washed 3 times with $5 \mathrm{~mL}$ PBS buffer $(\mathrm{pH}=6.5)$. Then adjusted the bacteria concentration to 1.00 at $\mathrm{OD}_{560 \mathrm{~nm}}$ by PBS buffer. $4 \mathrm{~mL}$ adjusted bacterial solution, $0.8 \mathrm{~mL}$ xylene were added to the sterile centrifugal tube in turn. After swirling oscillation and layering at rest for $10 \mathrm{~min}$, the water phase was taken out and determined $\mathrm{OD}_{560 \mathrm{~nm}}(\mathrm{~A})$. PBS buffer was used as blank control $\left(\mathrm{A}_{0}\right)$ [11].

$$
\text { Hydrophobicity } \left.(\%)=\left[\left(\mathrm{A}_{0}-\mathrm{A}\right) / \mathrm{A}_{0}\right)\right] \times 100 \% \text {. }
$$

\subsection{Preparation of the cell-free extracts}

The strain was cultured in MRS medium at $37^{\circ} \mathrm{C}$ for $24 \mathrm{~h}$ and passed on for 3 generations. After centrifugation for $15 \mathrm{~min}(5000 \mathrm{rpm})$, and the bacteria were collected. The bacteria number was adjusted to $10^{9} \mathrm{CFU} / \mathrm{mL}$ after washing by PBS buffer. The cell suspension was crushed by ultrasonic wave in ice bath at $4^{\circ} \mathrm{C}$ after centrifugation for $20 \mathrm{~min}(10000 \mathrm{rpm})$, the cell-free extracts were collected.

\subsection{Antioxidant capacity measure}

O-Phenanthroline $(2.5 \mathrm{mmol} / \mathrm{L})$, phosphoric acid buffer $(0.02 \mathrm{~mol} / \mathrm{L}, \mathrm{pH}=7.4)$ and distilled water $1 \mathrm{~mL}$ were added in the test tube in turn. After mixing, added $\mathrm{FeSO}_{4}$ ( $2.5 \mathrm{mmol} / \mathrm{L}) 1 \mathrm{~mL}$, mixed and added $\mathrm{H}_{2} \mathrm{O}_{2}(0.01 \%) 1$ $\mathrm{mL}$. $\mathrm{OD}_{536 \mathrm{~nm}}$ was measured after water bath at $37^{\circ} \mathrm{C}$ for $1 \mathrm{~h}\left(\mathrm{~A}_{1}\right)$. $\mathrm{A}_{0}$ was measured by adding $1 \mathrm{~mL}$ distilled water instead of $1 \mathrm{~mL} \mathrm{H}_{2} \mathrm{O}_{2}, \mathrm{~A}_{\mathrm{s}}$ was measured by adding $1 \mathrm{~mL}$ cell-free extract sample instead of $1 \mathrm{~mL}$ distilled water.

$$
\mathrm{OH} \text { scavenging rate }(\%)=\left[\left(\mathrm{A}_{\mathrm{s}}-\mathrm{A}_{1}\right) /\left(\mathrm{A}_{0}-\mathrm{A}_{1}\right)\right] \times 100 \% \text {. }
$$

$1 \mathrm{~mL}$ cell-free extract sample was added in $1 \mathrm{~mL}$ DPPH methanol solution $(0.2 \mathrm{mmol} / \mathrm{L}), \mathrm{OD}_{517 \mathrm{~nm}}$ was measured after $30 \mathrm{~min}$ of dark reaction at room temperature (A). Absorbance was measured with phosphoric acid buffer as blank control $\left(\mathrm{A}_{0}\right)$ [12].

DPPH radical scavenging rate $(\%)=\left[\left(\mathrm{A}_{0}-\mathrm{A}\right) / \mathrm{A}_{0}\right] \times 100 \%$.

\subsection{Data statistics}

The data statistical analysis was performed by using SPSS 19.0 software (SPSS Inc., Chicago, IL, USA). The comparisons of differences between the means of the treatments were tested by one-way ANOVA tests at a significance level of $p<0.05$.

\section{Results and discussion}

\subsection{Isolation and identification of LAB strains}

Three LAB strains were isolated from traditional fermented yogurt in Xinjiang, China. Based on the biochemical tests, all isolates showed Gram-positive, catalase-negative characteristics. And the isolates determined on NCBI by comparing with $16 \mathrm{~S}$ rDNA sequences of the standard strains. LP1, LP2 were classified as Lactobacillus plantarum, LD was classified as Lactobacillus delbrueckii subsp. Bulgaricus (As shown in Fig. 2 and Table 1). 


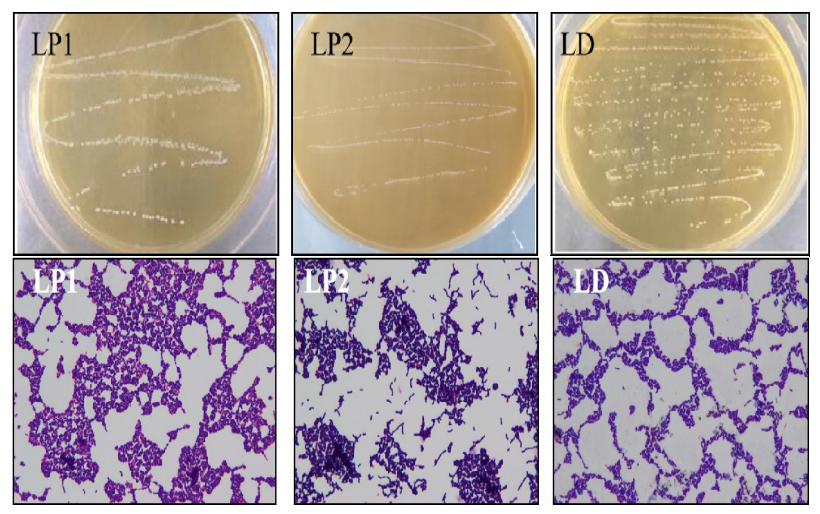

Fig. 2. Examination by MRS screening medium colonies and microscopy of LAB strains.

Table 1. Colony morphology of LAB strains.

\begin{tabular}{|c|c|c|c|c|}
\hline Isolates & $\begin{array}{l}\text { Gram } \\
\text { staining }\end{array}$ & $\begin{array}{c}\text { Catalase } \\
\text { test }\end{array}$ & $\begin{array}{c}\text { Colony } \\
\text { morphology }\end{array}$ & Microscopy \\
\hline LP1 & + & - & $\begin{array}{l}\text { Yellowish } \\
\text { cream color, } \\
\text { round, } \\
\text { edges clear }\end{array}$ & $\begin{array}{l}\text { Single or } \\
\text { paired, short } \\
\text { chain }\end{array}$ \\
\hline LP2 & + & - & $\begin{array}{l}\text { Cream } \\
\text { color, } \\
\text { round, } \\
\text { edges clear }\end{array}$ & $\begin{array}{l}\text { Single or } \\
\text { paired, short } \\
\text { chain }\end{array}$ \\
\hline LD & + & - & $\begin{array}{c}\text { Cream } \\
\text { color, } \\
\text { round, } \\
\text { edges clear }\end{array}$ & $\begin{array}{l}\text { Single or } \\
\text { paired, } \\
\text { slightly } \\
\text { rounded at } \\
\text { ends }\end{array}$ \\
\hline
\end{tabular}

\subsection{Tolerance to acid and bile salt test}

The $\mathrm{pH}$ of human gastric juice is usually maintained at about 3.0, probiotics stay in the stomach for 1-3 $\mathrm{h} \mathrm{[13].}$ So the artificial gastric juice of $\mathrm{pH} 3$ was selected to test the survival rates of $3 \mathrm{LAB}$ strains after $3 \mathrm{~h}$ of treatment. In Table 2, after isolates digested in artificial gastric juice for $3 \mathrm{~h}$, survival rates of isolates were 9.18\%$86.26 \%$. LP1 showed the best tolerance to acid of $3 \mathrm{LAB}$ strains.

Table 2. Tolerance to acid of LAB strains.

\begin{tabular}{cccc}
\hline Isolates & $\begin{array}{c}\text { 0h viable } \\
\text { counts } \\
(\mathrm{CFU} / \mathrm{mL})\end{array}$ & $\begin{array}{c}\text { 3h viable counts } \\
(\mathrm{CFU} / \mathrm{mL})\end{array}$ & $\begin{array}{c}\text { Survival rates } \\
(\%)\end{array}$ \\
\hline LP1 & $2.11 \times 10^{7}$ & $1.82 \times 10^{7}$ & $86.26 \pm 3.37^{\mathrm{c}}$ \\
LP2 & $6.20 \times 10^{6}$ & $4.68 \times 10^{6}$ & $75.49 \pm 2.26^{\mathrm{b}}$ \\
LD & $4.90 \times 10^{6}$ & $4.50 \times 10^{5}$ & $9.18 \pm 2.66^{\mathrm{a}}$ \\
\hline
\end{tabular}

Note: Significant differences were found between groups with different letter representations $(p<0.05)$.

Usually the concentration of bile salt in human small intestine is between $0.03 \%$ and $0.3 \%$. An important characteristic of probiotics are that they have a certain tolerance to bile salt in small intestine. This is also an basic condition to screen probiotics [14]. As shown in Table 3 , in $0.1 \%$ bile salt concentration, all isolates showed survival rates above $60 \%$. In $0.3 \%$ bile salt concentration, LP2 showed $60.08 \%$ survival rate which demonstrated the best bile salt tolerance in 3 LAB strains.

Table 3. Tolerance to bile salt of LAB strains.

\begin{tabular}{cccc}
\hline \multirow{2}{*}{ Isolates } & \multicolumn{3}{c}{ Survival rates (\%) } \\
\cline { 2 - 4 } & $0.1 \%$ bile salt & $0.2 \%$ bile salt & $0.3 \%$ bile salt \\
\hline LP1 & $80.37 \pm 2.33^{\mathrm{b}}$ & $66.85 \pm 2.99^{\mathrm{b}}$ & $54.24 \pm 2.64^{\mathrm{b}}$ \\
LP2 & $84.19 \pm 4.67^{\mathrm{c}}$ & $72.47 \pm 3.26^{\mathrm{c}}$ & $60.08 \pm 1.28^{\mathrm{c}}$ \\
LD & $61.34 \pm 3.92^{\mathrm{a}}$ & $38.40 \pm 2.87^{\mathrm{a}}$ & $14.91 \pm 1.34^{\mathrm{a}}$ \\
\hline
\end{tabular}

Note: Significant differences were found between groups with different letter representations $(p<0.05)$.

\subsection{Cell surface hydrophobicity test}

Cell surface hydrophobicity of LAB is one of the important factors determining the specific adhesion of LAB to biological and abiotic surfaces, and also one of the main factors affecting the absorption and degradation of hydrophobic organic matter by LAB [15]. So cell surface hydrophobicity test is also a important step for selection of LAB strains with probiotic properties.

As shown in Table 4, LAB strains showed cell surface hydrophobicity ranging from $65.34 \%$ to $24.18 \%$. LP1 showed the highest cell surface hydrophobicity that suggested that LP1 showed the best ability to adhere to the intestinal mucosa.

Table 4. Cell surface hydrophobicity of LAB strains.

\begin{tabular}{cccc}
\hline Isolates & LP1 & LP2 & LD \\
\hline $\begin{array}{c}\text { Hydrophobicity } \\
(\%)\end{array}$ & $65.34 \pm 2.24^{\mathrm{c}}$ & $51.83 \pm 3.12^{\mathrm{b}}$ & $24.18 \pm 1.83^{\mathrm{a}}$ \\
\hline $\begin{array}{l}\text { Note: Significant differences were found between groups with } \\
\text { different letter representations }(p<0.05) .\end{array}$ &
\end{tabular}

The stronger tolerance of LAB to human gastric juice and bile salt and stronger hydrophobicity of $\mathrm{LAB}$, the stronger colonization ability of LAB in intestinal tract, and the better function of LAB will be shown in human gastrointestinal tract [16]. The above results showed that LP1 has a good adaptability to simulated human intestinal environment in general.

\subsection{Antioxidant capacity of LAB strains}

Many free radicals are produced in the metabolic process of living organisms, free radicals can produce harmful compounds in the body's oxidative reaction, which can damage the body tissues and cells, and then cause chronic diseases and aging effects [17]. In recent years, redox has contributed significantly to the balance of gastrointestinal physiology and intestinal health, focusing on how oxidants in the gastrointestinal tract maintain the intestinal mucosal barrier and regulate complex host-pathogen interactions. Studies have shown that reactive oxygen species (ROS) are not only harmful by products of cell metabolism, but also key factors regulating intestinal homeostasis [18-21]. Hydroxyl 
radicals are the most active and therefore have strong oxidation ability [22]. So the antioxidant effect of LAB was determined by studying its scavenging ability to hydroxyl radicals. Also DPPH free radical scavenging rate is often used as one of the criteria to detect the antioxidant capacity of LAB [23]. The production of ROS is associated with a variety of gastrointestinal diseases. Therefore the screening of antioxidant LAB is very meaningful.

Free radical scavenging rates of cell-free extracts were shown in Table 5. LP1 showed the highest antioxidant capacity both in hydroxyl radicals and DPPH free radicals scavenging test $55.33 \%$ scavenging rate to hydroxyl radicals, $45.39 \%$ scavenging rate to DPPH free radicals).

Table 5. Antioxidant capacity of LAB strains.

\begin{tabular}{ccc}
\hline \multirow{2}{*}{ Isolates } & \multicolumn{2}{c}{ Free radical scavenging rate (\%) } \\
\cline { 2 - 3 } & Hydroxyl radicals & DPPH free radicals \\
\hline LP1 & $55.33 \pm 3.42^{\mathrm{c}}$ & $45.39 \pm 2.93^{\mathrm{c}}$ \\
LP2 & $49.90 \pm 2.95^{\mathrm{b}}$ & $24.73 \pm 2.49^{\mathrm{b}}$ \\
LD & $37.79 \pm 3.89^{\mathrm{a}}$ & $18.81 \pm 1.77^{\mathrm{a}}$ \\
\hline
\end{tabular}

Note: Significant differences were found between groups with different letter representations $(p<0.05)$.

\section{Conclusion}

This study confirmed the probiotic properties of LAB strains isolated from traditional fermented yogurt in Xinjiang consisted of tolerance to simulating human intestinal environment and antioxidant ability. Following the results we showed above, 3 LAB strains isolated from 5 kinds of yogurt samples were classified as Lactobacillus plantarum (LP1, LP2), and Lactobacillus delbrueckii subsp. Bulgaricus (LD). LP1 showed better tolerance to acid, cell surface hydrophobicity and antioxidant ability, LP2 showed better tolerance to bile salt comparing with the other two LAB strains. LP1 showed the best probiotic properties in general.

These results laid a theoretical foundation for our subsequent in vivo experiments on $\mathrm{LAB}$ strains from Chinese traditional fermented dairy products. And it is important for expanding probiotic bank with independent intellectual property rights in China and enhancing the function of fermented food. It also provides reference value for developing new functional probiotic products or new food starter in the future.

\section{Acknowledgement}

This work was financially supported by the Universitylevel Scientific Research Project of Chongqing University of Education (KY201705C) and the Funded Project of Young Backbone Teachers in Chongqing Colleges and Universities and the Program for Innovation Team Building at Institutions of Higher Education in Chongqing (CXTDX201601040), China.

\section{References}

1. D. Amenu, Curr. Res. Microbiol. Biotechnol. 1, 6 (2013)

2. M.C. Collado, J. Meriluoto, S. Salminen, Eur. Food Res. Technol. 226, 5 (2008)

3. P. Scottk, Cell Mol Life 59, 12 (2002)

4. K.K. Eun, J.L. Seung, H.M. Sang, et al, Food Chem. 117, 7 (2009)

5. P. Kanmani, R. Satish Kumar, N. Yuvaraj, et al., Crit. Rev. Food Sci. Nutr. 53, 6 (2013)

6. I. Amadou, G.W.Le, Y.H. Shi, Int. J. Food Prop. 16, 3 (2013)

7. P.A. Maragkoudakis, G. Zoumpopoulou, C. Miaris, G. Kalantzopoulos, B. Pot, E. Tsakalidou, Int. Dairy J. 16, 2 (2006)

8. J.P. Tamang, B. Tamang, U. Schillinger, et al., Int. J. Food Microbiol. 105, 3 (2005)

9. Chinese Pharmacopoeia Commission, Pharmacopoeia of People's Republic of China (China Medical Science, Beijing, 2010)

10. L. Morelli, Int. Dairy J. 17, 7 (2007)

11. R.J. Doyle, M. Rosenberg, Method Enzymol. 253, 54 (1995)

12. T.H. Kao, B.H. Chen, Food Chem. 54, 20 (2006)

13. R. Huang, X. Tao, C. Wan, S. Li, H. Xu, F. Xu, N.P. Shan, H. Wei, J. Dairy Sci. 98, 58 (2015)

14. B. Turchi, S. Mancini, F. Fratini, et al., World J. Microbiol. Biotechnol. 29, 10 (2013)

15. U. Schillinger, C. Guigas, W. Heinrich Holzapfel, Int. Dairy J. 15, 12 (2005)

16. J. Yu, W.H. Wang, B.L.G. Menghe, et al., J. Dairy Sci. 94, 7 (2001)

17. R. Xu, N. Shang, P. Li, Anaerobe 17, 5 (2001)

18. T. Kullisaar, M. Zilmer, M. Mikelsaar, et al., Int. J. Food Microbiol. 72, 3 (2002)

19. F. Sommer, F. Bckhed, Nat. Rev. Microbiol. 11, 22 (2013)

20. J.C. Largier, F. Armougom, M. Million, et al., Clin Microbiol Infect. 18, 11 (2012)

21. K.Y. Hur, M.S. Lee, Diabetes Metab J. 39, 19 (2015)

22. M.Y. Lin, C.L. Yen, J. Agric. Food Chem. 47, 4 (1999)

23. A. Amanatidou, E.J. Smid, M.H. Bennik, L.G. Gorris, FEMS Microbiol Lett 203, 1 (2001) 